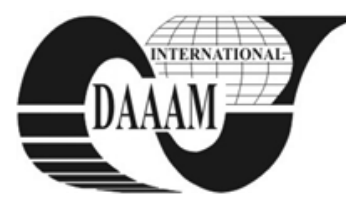

Annals of DAAAM for 2011 \& Proceedings of the 22nd International DAAAM Symposium, Volume 22, No. 1, ISSN 1726-9679 ISBN 978-3-901509-83-4, Editor B. Katalinic, Published by DAAAM International, Vienna, Austria, EU, 2011 Make Harmony between Technology and Nature, and Your Mind will Fly Free as a Bird Annals \& Proceedings of DAAAM International 2011

\title{
STUDENT PERCEPTION OF ONLINE SHOPPING AND WEB 2.0 TOOLS: THE CASE OF CROATIA
}

\author{
JAKOVIC, B[ozidar]; KNEZEVIC, B[lazenka] \& STRUGAR, I[van]
}

\begin{abstract}
Student population tends to intensively search for relevant information on product and purchasing processes prior to the purchasing decision. It can be expected that in the very near future this population will have a major impact on the online retail revenue generation. This paper examines the attitudes of students toward online shopping and Web 2.0 tools. The main findings show that more experienced Internet users are more likely to become online shoppers. A comparison of monthly income leads us to the conclusion that the higher their monthly income the more likely they are to shop online.
\end{abstract}

Key words: Web 2.0, e-commerce, online shopping, customer behavior

\section{INTRODUCTION}

Companies nowadays can't imagine doing their business without the use of the Internet and its technologies. At the beginning of the development of Web technologies companies owned informative Web site with basic information about the company. After that they started adding information about products and services offered to eventually develop into information Web portals.

Web portals are important channels of any organization through which it disseminates information about the organization. Organizations should pay adequate attention to fulfill customers' expectations and requirement (Esse \& Majerik, 2008)

\section{WEB PORTALS AND WEB 2.0}

O'Reilly Media organized the first conference devoted to Web 2.0 in 2004 and the term has been applied to any new Web-related activity. Web technologies let users work in the Internet cloud in the same way they work on their own desktops, but with the advantage of a collaborative culture. The key point is that the Web is the workplace, and users create the value. The key to Web 2.0 involves users to add value (Serrano \& Torres, 2010).

Major characteristics of Web 2.0 tools are openness, freedom and collective intelligence. Web browser became the platform for using Web 2.0 systems. Investments in the development of Web 2.0 systems very quickly generate a refund - ROI - return on equity (Ruzic \& Andrlic, 2009).

Web 2.0 tools may have been the most influential new media in decades. The Internet became an information channel used more and more, the consumers trusting it with $35 \%$ more in 2010 compare to the last year against television (Ratiu et al., 2010).

Attitudes of student population could be very significant when testing the possibilities of Internet as a communication channel for retail businesses. Moreover, the given population in a relatively short period is going to become crucial in decision making regarding larger purchases, so their attitudes towards Internet as a source of purchasing information will become even more important from the retailers point of view.

\section{METHODOLOGY \\ AND \\ SAMPLE DESCRIPTION}

In this research the survey was taken on student population. An online questionnaire was formed and it included 16 questions of different types: 7 one choice question; 9 Likert scale ranking questions and 3 questions had an open-ended option. The questions were divided into several groups: (1) Demographic characteristics; (2) Modalities and motives for Internet usage; (3) Online shopping behavior; (4) Attitudes towards online shopping issues.

Research took place in February 2011. The gathered poll consisted of 564 answered questionnaires and 550 of them were fully valid.

The gender structure of the sample was in the accordance with the student population within faculties of economics and business in Croatia. The sample consists of $71,8 \%$ of female and $27,8 \%$ of male students.

Monthly income in the sample corresponds to the structure of student population in Croatia. A huge proportion of students have monthly income (in terms of allowances, scholarships, wages and/or part time job fees) less than 1000 kunas (i.e. less than 135 EUR), while there is a certain proportion of working students that have a larger amounts of money available for monthly spending.

The majority of students use Internet for more than 7 years $(70 \%)$. There are only a few new Internet users at the sample $(0,2 \%)$. So we can conclude that this student generation has been growing up with digital technology since their childhood.

\section{RESEARCH RESULTS}

Turban (2008) gives a list of benefits of e-commerce for consumers and he emphasizes some of them. Students are asked to compare benefits of online stores to traditional stores. Ranking of benefits of online shopping is given in Tab. 1.

\begin{tabular}{|l|r|r|l|c|}
\hline Online shopping benefits & $\begin{array}{l}\text { rating } \\
\text { average }\end{array}$ & $\begin{array}{l}\text { (important+very } \\
\text { important)/TOTAL }\end{array}$ & mod & $\begin{array}{l}\text { mod } \\
\text { ITOTAL }\end{array}$ \\
\hline $\begin{array}{l}\text { I can purchase products which are } \\
\text { not available at my city/country }\end{array}$ & 3,9 & $73,06 \%$ & important & $37,43 \%$ \\
\hline $\begin{array}{l}\text { II is easier to compare prices and } \\
\text { product information }\end{array}$ & 3,74 & $65,16 \%$ & important & $39,17 \%$ \\
\hline $\begin{array}{l}\text { I can shop abroad without traveling } \\
\text { costs }\end{array}$ & 3,69 & $66,55 \%$ & important & $38,88 \%$ \\
\hline $\begin{array}{l}\text { II is easier to find interesting } \\
\text { products/services }\end{array}$ & 3,69 & $63,00 \%$ & important & $40,79 \%$ \\
\hline $\begin{array}{l}\text { There is no pressure by salesmen } \\
\text { like in traditional stores }\end{array}$ & 3,66 & $62,94 \%$ & $\begin{array}{l}\text { very } \\
\text { important }\end{array}$ & $33,21 \%$ \\
\hline I save my time & 3,57 & $58,59 \%$ & important & $35,44 \%$ \\
\hline $\begin{array}{l}\text { I have more time to choose and } \\
\text { evaluate products/services than in } \\
\text { traditional stores }\end{array}$ & 3,55 & $57,79 \%$ & important & $35,33 \%$ \\
\hline I can shop 24/7 & 3,51 & $55,68 \%$ & important & $33,51 \%$ \\
\hline $\begin{array}{l}\text { I can find products/services which } \\
\text { are not available at traditional stores }\end{array}$ & 3,47 & $53,44 \%$ & important & $32,97 \%$ \\
\hline $\begin{array}{l}\text { Offers are more favorable than in } \\
\text { traditional stores }\end{array}$ & 3,47 & $50,81 \%$ & moderate & $31,46 \%$ \\
\hline $\begin{array}{l}\text { I can focus to buy only necessary } \\
\text { products/services more easily (there } \\
\text { is less impulse buying) }\end{array}$ & 3,37 & $50,27 \%$ & important & $32,37 \%$ \\
\hline $\begin{array}{l}\text { Process of purchasing is more } \\
\text { simple and takes less effort than in } \\
\text { traditional stores }\end{array}$ & 3,27 & $43,74 \%$ & moderate & $31,76 \%$ \\
\hline
\end{tabular}

Tab. 1. Benefits of online shopping compared to traditional stores ranked by rating averages

Note: 1 - not important; 5 - very important 


\begin{tabular}{|l|r|r|r|r|}
\hline Answer Options & $\begin{array}{r}\text { Rating } \\
\text { Average }\end{array}$ & $\begin{array}{c}\text { (important } \\
\text { +very } \\
\text { important)/ } \\
\text { TOTAL }\end{array}$ & mod & mod/TOTAL \\
\hline information on payment possibilities & 4,21 & $83,12 \%$ & important & $43,67 \%$ \\
\hline information on delivery & 4,19 & $82,90 \%$ & important & $45,59 \%$ \\
\hline good reputation of online shop & 4,18 & $82,32 \%$ & important & $43,28 \%$ \\
\hline $\begin{array}{l}\text { well structured offer (product are } \\
\text { categorized, search tool is } \\
\text { available...) }\end{array}$ & 4,17 & $80,73 \%$ & important & $40,92 \%$ \\
\hline $\begin{array}{l}\text { contact tinformation (phone, fax, } \\
\text { mail, e-mail address) }\end{array}$ & 4,14 & $79,67 \%$ & important & $40,84 \%$ \\
\hline information on products/services & 4,13 & $79,30 \%$ & important & $43,59 \%$ \\
\hline $\begin{array}{l}\text { various payment options } \\
\text { added services (more value for }\end{array}$ & 4,11 & $78,13 \%$ & important & $42,83 \%$ \\
\hline money) & 3,95 & $73,03 \%$ & important & $47,16 \%$ \\
\hline free gifts for purchase & 3,45 & $47,99 \%$ & moderate & $36,45 \%$ \\
\hline $\begin{array}{l}\text { rich interactive web contents } \\
\text { (games, video, forums...) }\end{array}$ & 2,91 & $29,94 \%$ & moderate & $33,46 \%$ \\
\hline
\end{tabular}

Tab. 2. Elements important when compared with online shops ranked by rating averages

Note: 1 - not important; 5 - very important

In the table, the most frequent attitude towards each benefit is shown, too (see column "mod"). Availability of the product that is not sold at particular market is the most important benefit of shopping online. The possibility of comparing prices and products follows. The benefit "no pressure by salesmen" has the "very important" mod in 33,21\% cases.

When choosing an online shop to buy in, customers pay attention to various things, starting from the contents of the page, colors and design to products assortment structure. Table 2 compares some elements of online shops in accordance with students' attitudes towards the importance in decision process when choosing an online shop.

In order to examine the differences in student population in Croatia, the collected data was cross tabulated for two basic groups of students. The first group included students that have never made online purchase and group was named "non online shoppers". In the second group were students that made online purchase, regardless of the frequency of online purchasing within a year. That group was named "online shoppers". The sample included $54 \%$ of "non online shoppers" and $46 \%$ of "online shoppers".

With the intention to examine the differences between the given groups' chi-square tests and independent t-tests were performed. $\mathrm{P}$ value of $\mathrm{t}$-tests is presented in advance.

The male students are online shoppers in more cases than the female students (acceptable at significance level $\alpha=0,1$; $\mathrm{P}=0,0667)$. The online shoppers have higher monthly income than non online shoppers $(\alpha=0,05 ; \mathrm{P}=0,0000)$. Online shoppers use the Internet for a longer period $(\alpha=0,05 ; \mathrm{P}=0,0064)$ and more often than non online shoppers $(\alpha=0,05 ; \mathrm{P}=0,0287)$. On a daily basis, online shoppers spend more time online $(\alpha=0,05$; $\mathrm{P}=0,0002)$. Online shoppers perceive Internet motives to be more important than non online shoppers. For six out of ten motivations to use Internet (see Table 3), there is a statistically significant $(\alpha=0,05)$ difference between those two groups. Groups especially differ in two motives: (1) can shop without leaving home (mean difference is 0,97 ) and (2) can get information about products and services (mean difference is $0,53)$.

When comparing traditional and online stores, online shoppers are more favorable to perceive online shopping benefits than non online shoppers. Each answer option is shown in Table 1. The differences in means between groups range from 0,51 to 0,75 in favor of online shoppers and all $\mathrm{P}$ values are 0,0000 .

\begin{tabular}{|l|r|r|r|r|}
\hline & $\begin{array}{l}\text { MEAN } \\
\text { non online } \\
\text { shoppers }\end{array}$ & $\begin{array}{l}\text { MEAN } \\
\text { online } \\
\text { shoppers }\end{array}$ & difference & P value \\
\hline Internet usage motivation & 1,773333 & 2,741036 & 0,967703 & 0,0000 \\
\hline can shop without leaving home & 3,656766 & 4,187251 & 0,530485 & 0,0000 \\
\hline $\begin{array}{l}\text { can get information about products and } \\
\text { services }\end{array}$ & 3,781457 & 4,125 & 0,343543 & 0,0002 \\
\hline can read news on public media & 3,729373 & 4,056225 & 0,326852 & 0,0002 \\
\hline can download free multimedia contents & 3,870861 & 4,087302 & 0,216441 & 0,0060 \\
\hline $\begin{array}{l}\text { can watch and listen free multimedia } \\
\text { contents }\end{array}$ & 4,506623 & 4,613546 & 0,106923 & 0,0285 \\
\hline $\begin{array}{l}\text { can find general information of my } \\
\text { personal interest }\end{array}$ & &
\end{tabular}

Tab. 3. Statistically significant difference between online shoppers and non online shoppers regarding Internet usage motives perception

\begin{tabular}{|l|r|r|r|r|}
\hline Web 2.0 tool & $\begin{array}{l}\text { MEAN } \\
\text { non online shoppers }\end{array}$ & $\begin{array}{l}\text { MEAN } \\
\text { online shoppers }\end{array}$ & difference & P value \\
\hline forums & 2,421927 & 2,828685 & 0,406758 & 0,0000 \\
\hline Facebook & 3,735974 & 3,972222 & 0,236249 & $0,0746^{*}$ \\
\hline Wikipedia & 2,430464 & 2,580000 & 0,149536 & 0,0322 \\
\hline
\end{tabular}

Tab. 4. Statistically significant difference between online shoppers and non online shoppers regarding Web 2.0 tools Note: * significant at $\alpha=0,1$.

When discussing the frequency of web 2.0 usage, the picture is slightly different. For those students who use Web 2.0 tools, Facebook is commonly used more than once a day; it is followed by Youtube which is commonly used on a daily basis. On the other hand, Wikipedia and blogs are not used so frequently. The difference between the online shoppers and the non online shoppers is tested in the area of Web 2.0 tools, too. Table 4 shows statistically significant differences. The differences are significant in the usage of forums, Facebook and Wikipedia which are more frequently used within a group of online shoppers. The results in the paper are limited to Croatian student so future research should be conducted on students in different countries in order to be able to compare the results.

\section{CONCLUSION AND RECOMMENDATIONS}

Several facts such as: a high proportion of Internet users within the population, a high proportion of those who use Internet on a daily basis for more than three hours a day, a high proportion of those who use Internet for more than seven years and extremely high proportion of users seeking purchasing information online in order to buy product offline, brings us to the conclusion that retailers are facing experienced, well informed and digitally oriented customers within the students.

Moreover, the findings show that more experienced Internet users are more likely to be online shoppers. That is confirmed by the fact that online shoppers use Internet for a longer period of time and much more frequently on a daily basis compared to the non-online shoppers. Also, the comparison of monthly income leads us to the conclusion that the higher their monthly income the more likely they are to shop online. Retailers (both online and traditional) should develop web places rich in contents and information on merchandize adjusted directly to the student population. Online shoppers are more demanding when making comparison of online shops and they find web 2.0 tools as a source of information on the online shops, products and services more important than the non-online shoppers. Attention to social networks as a tool to reach targeted markets should be included into online communication strategy of retailers as well.

\section{REFERENCES}

Esse, M. \& Majerik, M. (2008) The project Web portal quality function deployement Annals of DAAAM for 2008 \& Proceedings of the 19th International DAAAM Symposium / ISSN: 1726-9679, ISBN: 978-3-901509-68-1, Katalinic, B. (Ed.). pp.483-484, DAAAM International, Vienna

Ratiu, M.P., Negricea, C.I. \& Oprescu, A.E. (2010) Analysis of the market of advertising services in Romania in the context of the present economic challenges Annals of DAAAM for 2010 \& Proceedings of the 21th DAAAM Symposium I ISSN: 1726-9679, ISBN: 978-3-901509-73-5, Katalinic, B. (Ed.). pp.751-752, DAAAM International, Vienna

Ruzic, D. \& Andrlic, B. (2009). Analysis of using internet technology in hospitality marketing Annals of DAAAM for 2009 \& Proceedings of the 20th DAAAM Symposium / ISSN: 1726-9679, ISBN: 978-3-901509-70-4, Katalinic, B. (Ed.). pp.91-02, DAAAM International, Vienna

Serrano, N. \& Torres, J. M. (2010) Web 2.0 for Practitioners, IEEE Software, pp. 11-15

Turban, E. (2008). Electronic Commerce: A Managerial Perspective, Pearson Education; ISBN-10: 9780132243315 